\title{
ICTs and Second Language Learning
}

Ângela Musskopf, Instituto Ivoti, e-mail: angela.musskopf@institutoivoti.com.br Débora Nice Ferrari Barbosa, Universidade Feevale, e-mail: deboranice@feevale.br

Patrícia B. Scherer Bassani, Universidade Feevale, e-mail: patriciab@feevale.br

\begin{abstract}
The present article aims to show the practices mediated by the use of educational digital resources developed with undergraduate students, which used three digital resources related to writing skills: a MOOC, the Text Inspector, and the Write and Improve. Furthermore, important discussions are made about the theories of Second Learning Acquisition and it's teaching methodologies, highlighting the approaches using online educational resources. The results of the practices show that the undergraduate students saw improvement in their developed skills, which indicates that the use of technological resources can contribute to the process of learning.
\end{abstract}

Keywords: educational technology. online resources. second language acquisition. learning.

\section{TICs e aprendizagem de segunda língua}

Resumo: O presente artigo tem por objetivo apresentar práticas mediadas pelo uso de recursos educacionais digitais desenvolvidas com estudantes da graduação, os quais participaram de um curso online aberto e massivo com enfoque na aprendizagem de Língua Inglesa, nos aspectos de vocabulário, gramática e escrita, além do uso de recursos como Text Inspector e Write and Improve. Além disso, são levantadas discussões importantes acerca das teorias de Second Learning Aquisiton (SLA) e suas metodologias de ensino, destacando as abordagens que envolvem o uso contextualizado dos recursos educacionais online. Os resultados das práticas demonstram que os graduandos perceberam melhorias nas habilidades desenvolvidas, o que indica como o uso de recursos tecnológicos pode contribuir para a aprendizagem.

Palavras chave: tecnologia educacional. recursos online. aquisição de segunda língua. aprendizagem.

\section{Introduction}

Currently, all areas have been invaded by technology: banking, marketing, commerce, and, of course, education. Schools cannot ignore this reality and should neither fear nor avoid integrating it inside the classroom. Thus, include possibilities of how to explore digital resources in teachers' formation courses is a must, it is a sine qua non to encourage future teachers to deal with the technological possibilities available, especially the ones that meet the characteristics of Second Language Acquisition (SLA) theories such as the digital educational resources used in this study. 
In education, the use of educational resources aims to develop and share digital tools to improve the learning process. According to UNESCO (2018, online), "Open Educational Resources (OER) are teaching, learning or research materials that are in the public domain or released with an intellectual property license that allows for free use, adaptation, and distribution".

The present article aims to describe a practice developed with teachers' training undergraduates using some digital educational resources. It also raises some issues about second language learning theories and approaches to language teaching based on authors such as Ellis (2000), Mitchel and Myles (2004) and Lightbown and Spada (2013), which can be linked to online learning. Furthermore, researchers such as Chapelle (2016) and Mello (1997) discuss the reasons to use ICTs in the classroom.

A positive feature of online resources is the fast feedback they can provide; most of them, besides assessing correct or incorrect answers, show some explanations on grammar points or rules that provide the theory to fundament the right answer. Another one is the result achieved: not only do they give numbers and/or percentages of right answers (for example $9 / 10=90 \%$ ) but also measure the quality of the given answers. These characteristics can lead learners to reflect and build knowledge so that they will be able to improve their language level. Therefore, the author considers educational resources should be included during the formation of undergraduates preparing to become teachers of English as a second language. Graduates students still leave universities without having experimented ICTs during their formation. The Survey on the Use of Information and Communication Technologies in Brazilian Schools (2017, p. 260) from 2016 illustrates this statement: 54\% of the teachers answered they did not have any specific subject on how to use computers and the Internet in activities with students during their Tertiary Education.

\section{Second Language Acquisition (SLA) and ICTs}

Second language learning (SLL) theories deal with the process of learning any other language different from the mother tongue as defined by Ellis (2001). Therefore, additional languages to the first, L3, L4 are as well considered in these studies. Thus, Ellis (2001) claims that there are diverse ways to discover how learners acquire their second language. In his opinion, "a better approach might be to find out what learners actually do, as opposed to what they think they do, when they try to learn an L2" (Ellis, 2001, p. 4). By this method, data from the language used by learners are collected and 
studied to verify the accuracy of the target language. Many factors can influence language acquisition as to remain incomplete. This author mentions as possibilities the need of the learner for more time, the subject simply stops learning, they can be motivated to learn only enough to communicate according to their necessity or just because they do not want to join the native speaking community.

Aiming to help students to acquire a second language, researchers refer to the cognitive approach, the functional/pragmatic perspective, the input and the interaction, the socio-cultural perspective and the sociolinguistic perspective as to aspects which influence the acquisition process. Cognitive approaches study basically "how the human brain processes and learns new information" (MITCHEL; MYLES, 2004, p. 95). Psychologists understand learning as the result of our brain turning controlled practices to automatic ones. These processes involve our short-term memory using new words and chunks and storing them in our long-term memory. This is achieved through repetition so that they will be available when requested. Once our brain automatizes simple forms, it can move on to more complex structures. This movement goes on continuously always from controlled to automatic processes.

According to Lightbown and Spada (2013), these approaches produced four main applications to second language learning: interacting, noticing, processing and practicing. Interaction relates to the necessity of opportunities for learners to communicate with other speakers looking for a mutual understanding through negotiation for meaning. Noticing relates to an essential point in learning since it states that the growth in language is only achievable if people become aware of language features. Processing refers to the sequence of features acquired by the learners and their development of syntax and morphology features. Practice relates to the essential part of using what was studied, preferably, it should be interactive, meaningful and focused on task-essential forms. All these aspects can be addressed by the use of digital educational resources: there are mind maps resources that help people to structure, plan and organize their thoughts, there are educational networks, such as Edmodo, that provide ways of interaction in a safe environment, and students do not feel afraid of exposing themselves, there are resources that provide practice and allow teachers to produce material specific to their classes, such as $\mathrm{ELO}^{1}$. According to Chapelle (2016, p. 10), "the variety of research methods for investigating technology and language learning has

\footnotetext{
${ }^{1}$ Available at: http://www.elo.pro.br/cloud/
} 
been integrally linked to theoretical perspectives on second language learning". Yet, she continues affirming that nowadays the relation between research practices and the second language learning are much more well established than two decades ago due to the fact researchers were able to make explicit connections of interactionist second language acquisition for the design of ICTs.

With the advance of technology and the ease of access, researchers have been looking for options to enhance language learning. Mello (1997) mentions that the Web provides awesome possibilities for education. Therefore, many programs, apps, and platforms have been developed lately, making available various resources and tools for teachers. Functional/pragmatic perspectives "are concerned with the ways in which second language learners set about making meaning, and achieving their personal communicative goals" (MITCHEL; MYLES, 2004, p. 131). This means that pragmatic communicative needs are the reason to develop a second language and once the communication goal is achieved, students may stagnate in their stage of knowledge thus explaining why some learners do not reach higher proficiency levels.

Input refers to the necessary exposure to the target language. Though it also can occur individually, interaction is the engagement with the interlocutor, which also provides input. Nevertheless, interaction here is not seen as an active role necessarily, as it can occur just by listening to a lecture, watching a movie or listening to a concert. In all these activities, people are being exposed to language, therefore it can be said there is a type of interaction. The sociocultural perspective and the sociolinguist perspectives (MITCHEL; MYLES, 2004) claim that input is not just a source of interaction, but it has a much more key role, for some researches, even being the ultimate nature of language. Sociocultural researches claim that the ultimate reason for language development is social, that is to interact with people and the environment. Most of these theories have been based on Vygotsky's work (MITCHEL; MYLES, 2004), applying his arguments to the learning of a second language. The sociolinguistic approach considers language in use. Some researchers deal with language variability, for example, the fact that people speak according to the social context they are in, while others develop studies of individual or group cases taking into consideration the learners' qualities and ambitions and their contribution to the context of learning. An important concept in this approach is the communities of practice, which are related to the identities of each person and the cultural society and community. Ethnographers have a great field of study to understand the second language used in speech events and communities. 
In 2000, Lee already listed eight benefits of using the internet for language learning: experiential learning, motivation, enhanced student achievement, authentic materials for study, greater interaction, individualization, independence from a single source of information and global understanding. Considering the updated state-of-theart of technology, there are many reasons to believe all these characteristics were implemented over the years, thus offering wider possibilities of exploitation.

Other researcher of technology in education is Jose Manuel Moran (2002, p.1), whose investigations are about distance learning and technology to transform education, claims that a good course is the one that excites, surprises, makes students think, provides active engagement and brings meaningful contributions putting students in contact with other people, experiences and interesting ideas. The usage of digital resources can meet these features, so why not include them in education and benefit from them? Technology allows teachers and students to respect their individualities without feeling bothered about timing since each one advances in their own pace, not causing waiting time for their colleagues.

\section{Digital Educational Resources for this practice}

For our practice, three digital educational resources were chosen: a MOOC, the Text Inspector, and the Write and Improve, all related to writing skills. There are three main reasons to use these ones: (a) writing productions are relatively easy to measure, (b) the meaningful use of the language, since students will engage in specific points to communicate and (c) the practice was developed in an institution that offers Cambridge Proficiency Tests, holding the title of a Preparation Centre, thus, it is important for the students to be in touch with the CEFR and tests standards.

A Massive Open Online Course (MOOC) $)^{2}$ allows a learner to participate in a course regardless of their geographical position as it can be joined all over the world. This MOOC was free of charge and allowed the participants to engage in forums to contribute with opinions, suggestions, practices and comments in each other's posts.

The Text Inspector ${ }^{3}$ was used to show to the student how to consider writing production according to the Common European Framework of Reference ${ }^{4}$ (CEFR). This resource is the result of a ground-breaking collaborative project, supported by the Council of Europe, and led by two departments of the University of Cambridge, UK.

\footnotetext{
${ }^{2}$ Available at: https://www.futurelearn.com/sign-in; the MOOC taken is unavailable now, therefore this is the main page address.

${ }^{3}$ Available at: http://www.englishprofile.org/wordlists/text-inspector; main page because it does not store information.

${ }^{4}$ Available at: http://www.cambridgeenglish.org/exams-and-tests/cefr/
} 
The CEFR describes what learners can do at different stages of their learning. By using this, students could realise their writing level and look for possibilities of levelling it up.

The Write \& Improve ${ }^{5}$, created by the University of Cambridge, marks writing accurately, attributing a score on the CEFR scale, giving it a level from A1 (lowest) to C2 (highest). It also shows the parts of the writing which may be improved by giving a feedback in two levels: word and sentence. In the word level, it gives you four types of feedback: incorrect word, forgotten word, forgotten word after another or suspicious word, all of them with a different symbol and colour to make feedback very clear to the students. In the level sentences, it gives you three types of feedback: a good sentence, a sentence that could be improved and a problematic sentence all of them highlighted and in assorted colours and shaded in different manners. Again, it is possible to connect this tool to all SLL theories because of the possibilities that it presents to students.

The main difference between the Text Inspector and the Write and Improve is that the first allows checking the level of any writing proposal while the second assesses only the proposals provided by the resource. Plus, the second resource gives feedback on vocabulary (spelling, misuse) and sentence structure (order of the elements, punctuation) whilst the first only classifies vocabulary according to the CEFR.

All resources are learning environments, and, with the exception of the Text Inspector, they demand to log in though free of charge and were approached through laptops in classes.

\section{Practice}

The undergraduate students took a five-week MOOC called A Beginner's Guide to Writing in English for University Study ${ }^{6}$, offered by University of Reading, UK. The goal of the course was to learn how to use English to study at university or college and develop the students' writing skills, vocabulary, and grammar. The students were guided on how to structure a paragraph and link them producing an essay at the end of the course. Besides this, since the first week, students were guided to write about a specific topic and to communicate their opinion and state their position. Moreover, the teacher collected their production throughout the course, discussed them in class with the students and allowed them to suggestion on how to continue their essays,

\footnotetext{
${ }^{5}$ Available at: https://writeandimprove.com/; main page to do the $\log$ in.

${ }^{6}$ Available at: https://www.futurelearn.com/sign-in; the MOOC taken is unavailable now, therefore this is the main page address.
} 
cooperating with each other. Students also used mind maps as a resource to plan their final essay.

The Text Inspector was used to check a writing proposal for a story. This was a sample of a Preliminary English Test (PET), level B1, from Cambridge, already used and available on their website ${ }^{7}$. The students received a task paper containing the instructions: your teacher wants you to write a story, the title is An exciting morning, write about 100 words. As in English proficiency tests, timing is a condition, the teacher allowed 45 minutes to the students fulfil the task and all of them manage to produce their story within it. After concluding, students used the text inspector to check the level of this writing production. After submitting the first time their texts, students were asked to look at the words categorized as unlisted since a great deal of them could be in such category because of spelling mistakes. The resource includes also names in this list, so students were advised to ignore it if the case. Afterwards, the teacher asked students to pay attention to the words categorised as A1 and A2 level and look for synonyms in higher levels and use them in their texts. The Online Thesaurus ${ }^{8}$ and the English Profile site itself helped students in this task. Afterwards, students resubmitted their writings and evaluated changes noticed through the numbers expressed.

The Write and Improve resource has three options of writing: beginner, intermediate and advanced besides specific writings for proficiency tests such as IELTS. For this group, the teacher chose an intermediate proposal for an article about learning English, titled: My reasons for learning English. The length of the production was set between 140 and 190 words, the amount demanded in the First Certificate in English (FCE) level B2 of the CEFR. Using this resource, students wrote their first version, reflected on the received feedback and were asked to rewrite and resubmit as many times as they wanted. Most of the students submitted their work two or three times. If they had a feedback, they were not able to deal with, the teacher was ready and prompt to help them.

\section{Results and final considerations}

Analysing the data collected after the practices, all students noticed improvements in their productions, seeing that the educational resources used allowed the possibility of comparison between the first draft and the final writing. Related to the

\footnotetext{
${ }^{7}$ Available at https:/www.cambridgeenglish.org/exams-and-tests/preliminary-for-schools/

${ }^{8}$ Available at: http://www.thesaurus.com/
} 
MOOC taken, it was the first time the students participated in one and they enjoyed this opportunity, especially because they had the chance to discuss their point of view and share ideas on how to continue developing it. The last writing was submitted to the text inspector which showed a clear difference from the first essay of the semester. Table 1 shows the improvement in the level of the words in two different productions. Though they were different writing proposals, it is clear that the entire group benefitted from the MOOC:

Table 1 - Comparison submitted to the Text Inspector

\begin{tabular}{|l|l|c|c|c|c|c|c|c|c|}
\cline { 3 - 10 } \multicolumn{2}{c|}{} & A1 & A2 & B1 & B2 & C1 & C2 & Unlisted & Total \\
\hline \multirow{2}{*}{ Student A } & First & 41 & 7 & 1 & 1 & 0 & 0 & 13 & 63 \\
\cline { 2 - 10 } & Final & 96 & 25 & 26 & 23 & 4 & 1 & 11 & 186 \\
\hline \multirow{2}{*}{ Student B } & First & 35 & 06 & 2 & 1 & 1 & 1 & 10 & 56 \\
\cline { 2 - 10 } & Final & 92 & 26 & 32 & 16 & 1 & 3 & 22 & 192 \\
\hline \multirow{2}{*}{ Student C } & First & 38 & 9 & 1 & 1 & 1 & 1 & 8 & 59 \\
\cline { 2 - 10 } & Final & 76 & 32 & 23 & 14 & 7 & 0 & 26 & 178 \\
\hline
\end{tabular}

As it can be seen, the achieved progress of all students was substantial, which means that the guidance of the resource, the discussions and moment of sharing ideas helped the student to produce a high-quality writing.

The task assigned with the Text Inspector and the substitution of the words using the Thesaurus was very interesting to the students. On one hand, because they did not know this was possible and on the other hand, due to the fact they were able to check the level of each word and learned new words and how to upgrade their own vocabulary. For example, when they typed in the Thesaurus the word happy, which is considered level A1 when used to express a feeling of gladness, they got as a synonym the word cheerful. Taking this word to the English Profile, there are two results; the first one expresses the same as the adjective happy and used like this, this word is considered level B2.

Table 2 - Level of vocabulary from the writings

\begin{tabular}{|l|l|c|c|c|c|c|c|c|}
\cline { 3 - 9 } \multicolumn{2}{c|}{} & A1 & A2 & B1 & B2 & C1 & C2 & Unlisted \\
\hline \multirow{3}{*}{ Student A } & Writing & 48 & 4 & 1 & 1 & 0 & 0 & 9 \\
\cline { 2 - 9 } & Rewriting & 48 & 7 & 4 & 2 & 0 & 0 & 1 \\
\cline { 2 - 9 } & & 0 & $75 \%$ & $300 \%$ & $100 \%$ & - & - & $88.88 \%$ \\
\hline \multirow{3}{*}{ Student B } & Writing & 43 & 14 & 7 & 2 & 0 & 3 & 9 \\
\cline { 2 - 9 } & Rewriting & 41 & 10 & 10 & 4 & 0 & 3 & 10 \\
\cline { 2 - 9 } & & $4.65 \%$ & $28 \%$ & $42 \%$ & $100 \%$ & - & 0 & $11 \%$ \\
\hline \multirow{3}{*}{ Student C } & Writing & 52 & 8 & 3 & 0 & 1 & 0 & 6 \\
\cline { 2 - 9 } & Rewriting & 51 & 8 & 2 & 4 & 2 & 1 & 2 \\
\cline { 2 - 9 } & & 1,92 & 0 & $33 \%$ & & $100 \%$ & & $67 \%$ \\
\hline \multirow{3}{*}{ Student D } & Writing & 49 & 8 & 6 & 1 & 0 & 1 & 2 \\
\cline { 2 - 9 } & Rewriting & 40 & 12 & 7 & 4 & 0 & 2 & 3 \\
\cline { 2 - 9 } & & $18,37 \%$ & $50 \%$ & $16 \%$ & $300 \%$ & - & $100 \%$ & $50 \%$ \\
\hline
\end{tabular}


Looking more closely at Table 2 , it is possible to notice that only one student maintained the same number of words in A1 level while the others had a decrease, which shows that the resource helped to upgrade the students' vocabulary. Yes, it is important to note the difference in levels B2, C1 and C2 as the current level of this class is considered B1 (low intermediate). Even though the number of words is not so high, all students were able to include vocabulary considered high intermediate and advanced, according to the CEFR. Throughout the time students were working on their texts inside the classroom, they were also engaging in conversation, helping each other's to use the resources and discussing ideas on what would be a good synonym to use, as the Thesaurus provides a list of options. Needless to say, they communicated in English even when talking about the words. After using these resources, once again, students were guided and became able to improve the level of their writings.

The Write and Improve provided an experience of inner conversation as the resource gave students feedback as commentaries so that students could reflect and try to solve the mistakes by themselves. During this practice, a curious situation happened: a student asked if the resource would also show a decrease if the case. The teacher asked the student to explore and check it. The first level achieved was A2 with a slight rise after resubmitting. However, because of a mistake in structure, in the third submission, it decreased showing that this may happen. The student felt satisfied and moved on to improve her writing, which had a significant increase from the first to the last submission.

To achieve the goals of each writing proposal, students were required to plan, organise, summarise, elaborate new language and ideas, all learning strategies connected to cognitive approaches. They had a reason to communicate in the second language, as functional approaches claim. Therefore, social-cultural approaches were also fulfilled. Since the MOOC was a writing for the university, the language used was formal, as students noticed while taking the course. Thus, they realised the difference between the language used in this context to an informal one, as stated by sociolinguistic approaches. Moreover, the data confirm that the use of educational resources are effective to second language learners. In the end, students became delighted and surprised with their development as well as motivated to use these resources in their own practice, which is this author's ultimate goal. Grounded on the theories of SLA related to ICTs and data collected during this practice, it seems undeniable that positive results were achieved through the linking of both areas. 
Consequently, digital educational resources should be taken into consideration during the Tertiary Education so that undergraduates may begin their professional life knowing how to deal with technological resources and feeling confident enough to use them with their learners. Nonetheless, more research is still necessary to discover all the possibilities of the resources described in this study and also others which are yet on hold to be analysed.

\section{REFERENCES}

CHAPELLE, Carol A. Call in the year 2000: a look back from 2016. Language Learning \& Technology, v. 20, n. 2, p. 159-161, June 2016. Disponível em: $<$ https://scholarspace.manoa.hawaii.edu/bitstream/10125/44468/1/20_02_chapelle.pdf $>$. Accessed in: 20 jun. 2018.

CHAPELLE, Carol A. Second Language Learning Online. In: ANDREWS, Richard; HAYTHORNTHWAITE, Caroline (Eds.). The Sage Handbook of E-learning Research. London: Sage Publishing, 2016. doi: 10.4135/9781848607859

ELLIS, Rod. Second Language Acquisition. Oxford: OUP, 2000. 147p.

LEE, Kuang-wu. English Teachers' Barriers to the Use of Computer-assisted Language Learning. The Internet TESL Journal Vol. VI, No. 12, December 2000 $<$ http://iteslj.org/Articles/Lee-CALLbarriers.html>. Accessed in: 29 jun. 2018.

LIG/HTBOWN, Patsy; SPADA, Nina. How languages are learned. Oxford: Oxford University Press, 2013. 324 p.

MELLO, Vera. Online Quizzes: Are they Worthwhile? The Internet TESL Journal, v. 3, n. 7, July 1997. Available at: <http://iteslj.org/Articles/Mello-Quizzes.html $>$. Accessed in: 20 jun. 2018.

MITCHELL, Rosamond; MYLES, Florence. Second Language Learning Theories. Banbury, UK: Hodder Arnold, 2004. 228p.

MORAN, JOSÉ MANUEL. O que é um bom curso a distância? Boletim do Programa Salto para o Futuro da TV Escola sobre educação a distância, 2002. Disponível em: $<$ http://www.tvebrasil.com.br/salto/boletins2002/ead/eadtxt1c.htm>. Accessed in: 29 jun. 2018.

PESQUISA SOBRE O USO DAS TECNOLOGIAS DE INFORMAÇÃO E COMUNICAÇÃO NAS ESCOLAS BRASILEIRAS [livro eletrônico]: TIC Educação 2016 - Survey on the Use of information and Communication Technologies in Brazilian Schools : ICT in education 2016 / Núcleo de Informação e Coordenação do Ponto BR, [editor]. -- São Paulo: Comitê Gestor da Internet no Brasil, 2017.

UNITED NATIONS EDUCATIONAL, SCIENTIFIC AND CULTURAL ORGANIZATION (UNESCO). Open Educational Resources. Available at: $<$ http://www.unesco.org/new/en/communication-and-information/access-tokowledge/open-educational-resources/>. Accessed in: 20 jun. 2018. 